\title{
COVID-19: The Impact on Air Transportation Tariff in Indonesia
}

\author{
Gunardi Gunardi $^{1 *}$ Moody R. Syailendra ${ }^{1}$ H.K. Martono ${ }^{1}$ \\ ${ }^{1}$ Faculty of Law, Universitas Tarumanagara, Jakarta, Indonesia \\ "Corresponding author. Email: gunardi@fh.untar.ac.id
}

\begin{abstract}
The COVID-19 pandemic has had a major impact in various areas of life. One of the areas that is hit by a huge impact is the air transportation field. The Tariff Limitation Policy causes a lack of flexibility for Business Actors in determining the appropriate tariff in order to survive this difficult time. The research method used in this research is legal research. Legal research is a process to find legal rules, legal principles, and legal doctrines to solve legal issues at hand. Based on the research that has been done, there is a need for new policies that can also help air transportation businesses to survive during the COVID-19 pandemic.
\end{abstract}

\section{Keywords: COVID-19, Tariff, Air Transportation}

\section{INTRODUCTION}

The COVID-19 pandemic (Corona Virus Desease 2019) has spread in Indonesia since the beginning of 2020. Various areas of life have suffered badly since the emergence of the COVID-19 Pandemic in Indonesia. One area that has been badly affected is the Aviation Industry. In fact, several airlines have had to go out of business because they were unable to survive this COVID-19 pandemic. In line with the development trend of the COVID-19 epidemic, which is claimed to be decreasing, gradually the aviation industry has begun to return to operations following the COVID-19 Protocol. Consumers as well as business actors must inevitably be able to adapt to the policy of limiting the number of passengers and the imposition of SIKM and COVID-19 test results as a prerequisite for someone to fly. But then new problems emerged along with the implementation of new protocols in the Aviation Industry. With this new protocol, it will reduce demand and increase airline operating costs. Currently, the government has regulations governing the Upper Tariff (TBA) and the Lower Limit (TBB) of Aircraft. With this pandemic condition, the Government is deemed necessary to evaluate and change this policy so that the Aviation Industry can survive the difficult situations during the Pandemic.

\subsection{Our Contribution}

This paper presents to provide additional scientific insights and contribute as an input to the government in determining policies regarding air transportation tariffs. The Government needs to evaluate current tariff policy, since it is considered ineffective in reviving the competitiveness of current aviation business actors. With new policy, it is hoped that the aviation industry can continue to operate during this pandemic.

\subsection{Paper Structure}

The rest of the paper is organized as follows. Section 2 will discuss the flight agreement and basic principles of tariffs. Furthermore, it will also discuss the air transportation tariff policy in Indonesia. Section 3. Section 4 discussed the impact of COVID-19 on air transportation tariffs in Indonesia, along with policies that can be proposed to the government in determining air transportation rates. Section 5 provides conclusions and inputs that can be provided based on the research results, particularly for the government in determining air transportation tariff policies.

\section{BACKGROUND}

\subsection{Chicago Convention 1944}

Since discussing the 1944[1] Chicago Convention, which is known as the constitution of international civil aviation, international air transportation has been discussed by the United States, Britain, Canada and the joint proposal of Australia and New Zealand. As far as technical and operational matters are concerned, all participants who were present can accept the provisions stipulated in the 1919[2] Paris Convention, but as long as economic issues include routes, flight frequency, aircraft type, seating capacity and fares, there is a difference of opinion between the United States (US), England, Canada as well as a joint proposal from Australia and New Zealand. The US, whose ideology is liberal, wants the government not to interfere with the economic problems of air transportation, which consists of flight routes, flight frequency, aircraft type, seating capacity and fares, let the airlines handle economic problems based on market law (supply and demand), on the contrary, the UK proposes that economic matters are fully regulated by the government[3], no flights from or to or through Britain 
including its colonies regulate the economy without prior approval by the British government, while Canada proposes that economic matters be regulated by the International Air Authority (IAA) not regulated by airlines such as the US proposal and not regulated by the government like the British proposal, while the joint proposal for Australia and New Zealand to form an airline company whose shares are owned by the member countries.

As far as the economy of air transportation is concerned, trial participants fail to agree on air transportation arrangements, thereby giving birth to Article 6 of the 1944 Chicago Convention which states that scheduled international flights can be made to member countries unless prior permission is obtained. As a result of this failure, the United States and Britain made the 1946 Bermuda agreement. The 1946 Bermuda Agreement for 30 years was considered a very good agreement, so that during that time, there was no country that did not have a Bermuda type agreement, Indonesia itself also had a 1946 Bermuda type agreement with The United States was signed January 13, 1968.[4] The 1946 Bermuda Agreement regulates flight routes, seating capacity and air transportation fares which were a compromise of dissent when discussed at the Chicago conference in 1944.

In order not to fail in regulating the economy, the Chicago conference in 1944 also approved the International Air Services Transit Agreement (IASTA) which exchanged the rights of first freedom of the air, second freedom of the air; International Air Transport Agreement (IATA), which exchanges the 3rd, 4th and 5th of the air in addition to ratifying the Chicago Standard Form Agreement.

\subsection{Air Transportation Agreement in Indonesia}

Indonesia as an ICAO member country [5], based on Article 6 of the 1944 Chicago Convention and Article 86 (2) of Law Number 1 of 2009, Indonesia also entered into a reciprocal international air transportation agreement to carry out international flights. Until 1979 Indonesia had international air transportation agreements for no less than 25 countries. Like other ICAO member countries, the air transportation agreement in Indonesia also regulates flight routes consisting of various route structures; airports of departure, intermediate landing, destination airports; connecting flights; passenger flow; seating capacity; equal opportunities for international flights; passenger fare etc. in accordance with the reference issued by ICAO [6][7], in addition to referring to the 1946 Bermuda agreement as mentioned above.

The implementation of the reciprocal air transportation agreement depends on their national law, whether the reciprocal air transportation agreement is implemented or not depends on them, even the country has the right to terminate the air transportation agreement without any reason. In relation to Covid-19, the treaty partner countries can prohibit their national airlines from flying to Indonesia to prevent the spread of Covid-19 which has resulted in a reduction in international passengers traveling to Indonesia, which in turn threatens the growth of the tourism industry which consists of hospitality, travel, business. home stay, recreation and all its derivatives. Indonesia cannot do much because it is the policies of other countries, even Indonesia itself, in the context of preventing the spread of Covid-19 which also prohibits overseas airlines from protecting the safety of passengers and flight crew.

\subsection{Tariff}

$\boldsymbol{F}$ ares play an important role for passengers, airlines and the government. For passengers, very high rates result in passengers unable to enjoy flight services optimally. On the other hand, for airlines, tariffs that are too low can threaten the survival of the airlines. Meanwhile, for the government, the tariff is a means of balancing the needs of the people and the survival of the airlines. Therefore, tariffs during the Old Order, New Order, relaxation policies and Law Number 1 Year 2009 were always regulated and monitored.

In the world of flights, there are terms known as tariffs, rates and fares. Tariffs are fees that must be paid in return for the carriage of a passenger, including commission, agency and other fees. Therefore, if (previously) a passenger bought a ticket directly from an airline company, he had to pay $100 \%$ of the official ticket price, but when buying through an agent he only paid $97 \%$ of the ticket price because the agent received $7 \%$ commission divided by $3 \%$ passengers and $4 \%$ agent. Fares are fees that must be paid for a passenger when using air transportation services, while rates are the cost that must be paid by the sender of goods per kilogram $(\mathrm{kg})$.[8] Regarding aircraft rates, the Minister of Transportation issued Decree Number KM 9 of 2002, which revoked the previous decrees. The Decree of the Minister of Transportation Number KM 9 of 2002 regulates basic tariff guidelines consisting of distance groups $(\mathrm{km})$ and tariffs on a per pax / $\mathrm{km}$ basis. The scheduled commercial air transport passenger rates do not include value added tax (known as "PPn"), compulsory insurance fees for passenger accidents from PT Jasa Raharja, other additional insurance, aircraft passenger service fees charged in accordance with applicable regulations. Any levies relating to air transport rates must be approved by the Minister of Transportation.

In addition to the Decree of the Minister of Transportation Number KM 9 of 2002, the Minister of Transportation also issued a Decree of the Minister of Transportation Number KM 8 of 2008, which regulates the procedures for submitting tariff rates to the Minister of Transportation after considering economic conditions accompanied by attachments for calculating aircraft operating costs, justification for tariff adjustments basis and / or tariff distance from the discussion results. According to the decree, the basic tariff is obtained from the calculation of the average cost of goods plus the profit with a cost component consisting of fixed costs and indirect variable costs consisting of organizational and marketing costs. Details of the basic tariff cost components are attached to the Minister of Transportation's decree. 


\subsection{General Principles of Tariff}

The transportation agreement between Indonesia and India regulates the general principle of tariffs. In general, the tariffs stipulated in the Indonesian air transportation agreement, with various editorial variations, determine that the tariff must be reasonable by taking into account the Bermuda I agreement of 1946. As an illustration of the tariff provisions stipulated in the air transportation agreement between Indonesia and India as follows:

\begin{abstract}
"Tariffs on any agreed service shall be established at reasonable levels, due regard being paid to all relevant factors including the cost of operation, reasonable profit, characteristics of services (such as standard of speed and accommodation) and the tariffs of other airlines for whole or part of the specific route."
\end{abstract}

Another principle, in the Indonesian and Chinese agreements, stipulates that the minimum amount of fares imposed by airlines designated on the same routes or sectors must be approved by the Indonesian government and the Chinese government, so that it does not affect the others. It should be noted here that the air transport agreement between Singapore and the United States determines cheap tickets that are favorable for both passengers and shippers. The agreement says that Singapore and the United States will push for low-cost tickets as low as possible.

\subsection{Indonesian Aviation Law}

Air transportation policy based on UURI No.1 Year 2009 adheres to a neo-liberal ideology which is a combination of socialist and liberal ideologies, therefore economy class tariffs are regulated by the government to ensure the interests of the general public, while non-economic fares are left to airlines based on market law (supply and demand) to ensure the survival of the airlines. In the neo-liberal tariff regulation policy, there is still competition based on the services provided, such as full services, medium services and no-frill services, route competition, aircraft types.

Competition in the field of tariffs is very tight by airlines, therefore airlines make various types of fares based on the time of departure, day of departure and month of departure. The most expensive fare based on the departure time is departing from 04.30 to 09.30 , the cheapest at 12.00-15.00 hours, while the cheapest fare based on the day of departure flies Tuesday, Wednesday and Thursday while the most expensive flies Friday, Saturday, Sunday and Monday. Based on the month of departure the most expensive are school holidays, Idul Fitri, Christmas and New Year, while in normal months the price is normal.

There are other types of competition, such as promo rates, flexible rates, normal rates, discount rates and others depending on the situation of the passenger. Even changing the time of departure the price can be different. Based on the neo-liberal policy, the freedom to determine any tariff as long as it does not exceed the upper limit and is not lower than the lower limit tariff as stipulated in the Minister of Transportation KM 11/2006. If it is lower than the lower limit price, it will threaten aviation safety. Government noneconomic tariffs do not determine, let the airlines determine based on market law to ensure the continuity of the company. For information, there is an airline that sets flights from Jakarta to Schippol in the Netherlands, which charges US \$ 6,500 while Jakarta-Solo charges Rp. 4,700,000, this is allowed but only a few executive seats are assigned.

As mentioned above, to implement the neo-liberal policy has been issued through KM 9 of 2002, which contains basic guidelines for determining tariffs consisting of distance $(\mathrm{km})$ and pax / $\mathrm{km}$ tariff groups. The passenger rates do not include VAT, Compulsory Insurance (Jasa Raharja), Voluntary Insurance etc. relating to passenger rates must be approved by the Minister of Transportation, in addition to the Decree of the Minister of Transportation Number KM 11 of 2006, which is commonly referred to as lower bound rates to regulate tariff scope and scope. supervision.

The scope of the tariffs arranged must pay attention to the safety and security of the flight, while the scope of monitoring of violations is evidenced by ticket payments and / or other proof of payment, news agents in printed and / or electronic social media as well as brochures / leaflets or advertisements in the media. print / or electronic, information and / or reports from users of airline services and / or organizations related to the aviation sector. If a violation is proven, the Director General of Civil Aviation immediately performs special supervision and if proven must provide corrections.

Apart from regulating the lower limit tariff, Law No.1 / 2009 also regulates the upper limit tariff to ensure the interests of the public. The limit rates set by the Minister of Transportation must be published through print and electronic media and / or posted at every place where airplane tickets are sold to consumers. This provision is forcing, meaning that domestic scheduled airlines are prohibited from selling airplane tickets above the price set by the Minister of Transportation with a warning sanction and / or revocation of flight route permits. The problem is that the capacity is reduced, the upper limit rate must be increased so that the company's revenue can cover costs.

\subsection{Tariff Regulations on the Upper Limit of Airline Tickets in Indonesia}

Currently, airplane fares are regulated with a lower limit rate (here in after-TBB) and an upper limit rate (here ini after-TBA). The TBB policy emerged in 2016 to prevent airlines from setting prices that are too low, thus sacrificing safety aspects. In subsequent developments, a TBA policy emerged that restricts prices from getting too high.

The Ministry of Transportation of the Republic of Indonesia on May 15, 2019, issued a Decree of the Minister of Transportation Number 106 of 2019 concerning the Upper Limit Rate of Economy Class Passenger Services for Domestic Scheduled Commercial Air Transport (KM 106/2019). KM 106/2019 is effective as of the date of 
stipulation. This policy was lowered in the context of the Government's efforts to reduce airplane ticket prices which were considered very expensive at that time.

Scheduled Commercial Air Transport Business Entities / airlines to set economy class fare / ticket prices on domestic routes, with a reduction of $12-16 \%$ compared to the amount of the Upper Limit Fare set by KM 72/2019. Furthermore, it should be noted that the application of the Upper Limit Fare is only applied to flights using jet airplanes. With a reduction in the Upper Limit Fare, it is hoped that airlines can sell airplane tickets at a lower rate / price so as not to burden the public and also maintain the level. passenger entry, which is operationally and commercially positive.[8]

\section{METHODS}

According to Peter Mahmud Marzuki, "Legal research is a process to find legal rules, legal principles, and legal doctrines in order to address legal issues at hand".[9] Therefore, the type of research used in juridical normative research is descriptive, which explains the impact of the COVID-19 pandemic on air transportation in Indonesia. The research was conducted by collecting legal materials and non-legal materials to determine the applicable tariff policies during this pandemic

\section{THE IMPACT OF COVID-19 ON AIR TRANSPORTATION TARIFFS IN INDONESIA}

In this pandemic situation, although flights have been permitted to operate, business actors have not fully benefited. This is due to passenger restrictions which of course have a direct impact on opinion, while on the other hand operational costs increase. At present, there are two things that are the focus of the government which are two sides of the money that are interrelated with each other, namely the health protocol and economic or business recovery.[10]

This condition is further exacerbated by the existence of the Upper Limit Tariff policy that has been determined by the government through KM106 / 2019, whereas on the other hand, if we look at other countries, in ASEAN for example, only Indonesia still applies this policy. We can refer to Malaysia and Thailand, in these countries the domestic aviation market is quite large, but the tariff restriction is no longer in effect. The author argues that, with the existence of tariff restrictions, it has not been able to support the aviation business, especially in dealing with the COVID-19. Both conditions can cause huge losses to air transportation business actors.

Furthermore, the question arises about whether to revise the setting of the upper limit tariff, which is possible. Or has the era of affordable aviation ended during this pandemic? Previously, the government through KM88 / 2020 had increased the upper limit rate for economy class aircraft. This regulation is temporary in nature as a government effort to maintain the sustainability of the aviation industry during this Pandemic. The increase is at least 50 percent of the TBA in accordance with the designated service groups. There are various factors that led to the issuance of this regulation, including the rupiah exchange rate, the selling price of avtur fuel, and operational costs per passenger for jet aircraft and 40 percent for propeller aircraft due to the implementation of Large-Scale Social Restrictions (PSBB). The amount of TBA which is determined does not include the calculation of Value Added Tax (VAT), compulsory contributions to the insurance fund from PT. Jasa Raharja (Persero), other additional costs, and the tariff for air passenger services (PJP2U). With this regulation coupled with the issuance of the Minister of Transportation Regulation Number 41 of 2020 which removes the 50 percent passenger restriction, it can provide fresh air for business actors. However, in practice, business actors must apply strict health protocols and this policy should always be discussed with INACA, airlines, and the task force for handling COVID-19.

In the flight business there are characteristics inherent in it. This characteristic is a fixed capacity with the product (seat) that will be wasted if it cannot be sold. Success in this field of business has been found in the ability to manage prices and capacity in such a way that as many seats as possible can be sold at a favourable average price level. This means that not all seats have to be sold at a favourable price (above the base price). There are chairs that are sold profitably, but there are also chairs that are sold at a loss. Selling chairs at a loss is still better than empty seats because the operating costs are relatively the same regardless of the seats occupied. It is the chairs that are sold at a loss which then becomes a gimmick for cheap flights. Regulating how many seats are sold at what price and when is the essence of the initiative known as revenue management. Since it was first introduced by American Airlines, it has been at the heart of this business.

During this time of the COVID-19 Pandemic, demand for aviation services tends to fall. This occurs due to community concerns about doing activities outside the home. To be able to sell available seats, airlines need flexibility in determining prices. If a business actor can predict demand on a flight that is likely to be low, they can offer some seats at a low price. Thus, flying with many empty seats can be prevented. In order to ultimately be able to sell all seats at a favourable average price level, the airline must sell some of its seats again at a high price. Pricesensitive leisure travellers will buy cheap tickets, while business travellers who are not price-sensitive will not mind buying expensive tickets.

To be able to determine expensive and cheap tickets, of course, different terms and conditions are needed. In its technical implementation, complicated formulas and algorithms are needed so that it requires the support of a sophisticated technology-based system. With the existence of tariff restrictions, this can cause business actors to be constrained in doing so. If the TBB is abolished, but the TBA is maintained, the airline cannot sell cheap chairs and there are no high-priced seats as compensation. This can lead to lost opportunities for business travellers, who are also willing to pay high prices to buy these seats. On the 
other hand, the opportunity for leisure travellers who tend to buy cheap prices will also disappear.

If the TBB is retained and the TBA is removed, the risk the airline faces is limited to unsold seats when demand tends to be low. If TBB and TBA are removed, airlines have the discretion to endeavor to regulate prices and seat allocations so that both risks can be reduced as low as possible. The effectiveness of revenue management is also determined by the ability of business actors to recognize demand patterns. With this pandemic, of course, it will result in changing demand patterns. Business actors must look for new patterns in order to determine the price of the seats being sold. One way to recognize this change in pattern is by conducting various experiments. Of course, by eliminating TBB and TBA, it is possible to implement this. With the existence of TBB and TBA, revenue management cannot be used, even though this is the main life of the aviation business sector.[11]

On the other hand, with the discourse on eliminating TBB and TBA, there is a fear of sacrificing safety aspects. According to the author, this can actually be overcome by increasing compliance and discipline and implementing good standard safety procedures. Of course, the Ministry of Transportation has a crucial role in supervising and ensuring this is consistently implemented by business actors. To prevent safety aspects from being sacrificed, the government can ask airlines to periodically report the CASM and RASM. These two things can indicate whether a business actor is neglecting safety in order to increase income. In addition, the use of RASM as a performance measure will stimulate airlines to seek ancillary revenue initiatives, such as the utilization of unused baggage capacity for cargo.

With the elimination of TBA, is there a possibility that business actors may increase the price as high as possible? As long as the competitive conditions are kept as competitive as possible and the supervisory function is running well, of course this concern can be overcome. If there is an indication of fraud by a business actor, the Business Competition Supervisory Commission (KPPU) can step in to investigate it. Many other countries have also been able to guarantee aspects of aviation safety and fair competition without using tariff policies or instruments, for example Singapore. What about policies to reduce costs, such as tax breaks and lower airport fees? A separate study conducted by McKinsey and A.T Kearney found that revenue management initiatives were able to increase operating profit by $8-11 \%$, much higher than fixed cost savings initiatives of only $2 \%$. In other words, the cost reduction incentive will reduce the burden on the airline, but the impact will not be significant.

\section{CONCLUSIONS}

Based on the explanation given by the author, there is actually the most basic thing, namely the government's mindset in implementing the management of the aviation industry. It can be said that tariff restrictions are the easiest solution that can be provided by the government in maintaining the validity of the safety aspects of aviation, besides this policy can also be interpreted as parting with the government towards consumers in order to enjoy cheap flights. However, if you look at it later, it turns out that this policy is what can eliminate cheap flights, because with this policy during the COVID-19 Pandemic, it is highly likely that airline business actors will not be able to survive and go out of business. Tariff restrictions will also eliminate the role of revenue management, which has been the lifeblood of this business sector.

The author argues, policies made by the government must support business actors in order to survive in this pandemic situation. Cheap flights are still difficult to implement, especially during the COVID-19 pandemic. In the end, don't let the epidemic end, business actors are unable to carry out their business activities because they cannot survive during the pandemic. By removing the tariff restriction policy, airlines can be helped in surviving this difficult time.

\section{ACKNOWLEDGMENT}

This work was supported by International Conference, Business, Social, Humanities (ICEBSH), Faculty of Law, Universitas Tarumanagara, Jakarta: Indonesia.

\section{REFERENCES}

[1] ICAO Doc.7300/8, Covention on International Civil Aviation, Signed at Chicago on 7 December 1944; texts dapat dilihat pada Dempey P.S.Ed.,Annals of Air and Space Law, (2005), Vol.XXX - Part I. Toronto, Canada : The Carswell Company, Ltd.hal.19-51.

[2] Convention Relating to the Regulation of Aerial Naviation, Signed at Paris on 13 October 1919

[3] Martono K.,Usman Melayu.,Perjanjian Angkutan Udara di Inodnesia, (Penerbit Madar Maju, Bandung, 1996), page. 37.

[4] Air Transport Agreement Between the Government of the United States of America and the Government of the Reppublic of Indonesia, Signed at Jakarta on January $13^{\text {th }}, 1968$

[5] Dempsey P.S.Ed.,Annals of Air and Space Law, (2005), Vol. XXX - Part I. Toronto, Canada: The Carswell Company Ltd.

[6] ICAO Doc.9228-C/1036, Standard Bilateral Tariff Clauses. Montreal, 1978; Circular 63-AT/6, Handbook on Administrative Clauses in Bilateral Agreement, Montreal,1962; Circular 72-AT/9 Handbook on 
Capacity in Bilateral Air Transport Agreement, Montreal, 1965; Circular 137-AT/43 Regulation of Capacity in International Air Transport Services, Montreal 1978.

[7] Amad Sudiro, Regulating Ballistic Missile Usage for Ensuring Civil Aviation Safety: As a Matter of Urgency, Vol 11, Journal of East Asia and International Law, 2018.

[8] Masyarakat Hukum Udara, "Regulasi Tarif Batas Atas Tiket Pesawat di Indonesia", http://masyarakat hukumudara.or.id/regulasi-tarif-batas-atas-tiketpesawat-di-indonesial

[9] Peter Mahmud, Penelitian Hukum, (Kencana Prenada Media Group, Jakarta, 2011), page. 35.

[10] Detik, "Kebijakan New Normal Tarif Pesawat", https://news.detik.com/kolom/d-5066511/kebijakannew-normal-tarif-pesawat.

[11] Kompas, "Maskapai Hadapi Dampak COVID-19, Tarif Batas Atas Perlu Dikaji Ulang?", https:// money.kompas.com/read/2020/06/09/151207826/maska pai-hadapi-dampak-covid-19-tarif-batas-atas-perludikaji-ulang $?$ page $=$ all . 